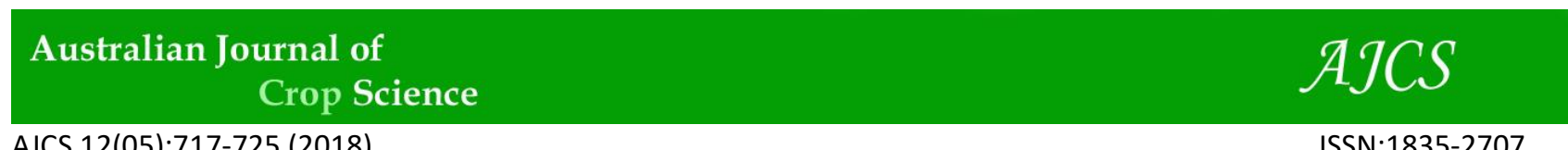

AJCS 12(05):717-725 (2018)

doi: 10.21475/ajcs.18.12.05.PNE821

ISSN:1835-2707

\title{
Adaptability and stability of grain yield in soybean
}

\section{Daniel Augusto Silveira ${ }^{1}$, Carlos André Bahry ${ }^{2 *}$, Luiz Fernando Pricinotto ${ }^{3}$, Maicon Nardino ${ }^{4}$, Ivan Ricardo Carvalho $^{4}$, Velci Queiroz de Souza ${ }^{5}$}

${ }^{1}$ Syngenta Crop Protection LTDA, Londrina, Paraná, Brazil

${ }^{2}$ Federal Technological University of Paraná, Dois Vizinhos, Paraná, Brazil

${ }^{3}$ Secretary of State for Agriculture and Supply, Cianorte, Paraná, Brazil

${ }^{4}$ Federal University of Pelotas, Pelotas, Rio Grande do Sul, Brazil

${ }^{5}$ Federal University of Santa Maria, Frederico Westphalen, Rio Grande do Sul, Brazil

\section{*Corresponding author: carlosbahry@utfpr.edu.br}

\begin{abstract}
The aim of this work was to analyze the adaptability and stability of soybean grain yield in fifteen environments in Paraná through different methodologies. Trials were conducted to test the genotypes SYN 1049; SYN 1152; SYN 1059; SYN 3358; SYN 1163; and, SYN 1157, at five sites with three different sowing times in 2011/2012 season. The analyzed character was grain yield per hectare. The analysis of adaptability and stability was performed by bissegmented regression, factors analysis and AMMI analysis. The estimates of the environmental indices by the tested analyses were partially concordant regarding the classification of the environments as favourable or unfavourable to the cultivars. Both the factor analysis and the AMMI analysis allowed the classification of the cultivars in relation to the specific environmental conditions. The soybean cultivars SYN 1059 and SYN 1163 revealed specific adaptability for the three analysis methodologies. Stability was also revealed through the bissegmented regression and the IPCA1 vs. mean methods.
\end{abstract}

Keywords: Favorable environments; Gx E interaction; Glycine max (L.) Merril; soybean cultivars; unfavourable environments. Abbreviations: AMMI_Additive Main Effects and Multiplicative Interaction Analysis, GxE_Genotype x Environments, IPCA1_ Interaction Principal Component Analysis Axis 1.

\section{Introduction}

The soybean (Glycine max L. Merril) is among the most economically important crops in Brazil, occupying a prominent position, which justifies the need for constant research in order to better exploit the genetic potential of cultivars and reduce risks and losses (Cavalcante et al., 2014). The soybean cultivars currently marketed domestically are indicated for cultivation in very different environments with regards to their edaphoclimatic conditions. The performance of breeding lines and/or cultivars is largely influenced by the genotype $(G) x$ environment $(E)$ interaction, making it difficult to identify materials with high productivity and stability due to environmental variations (Branquinho et al., 2014). The G x E interaction is important since it limits the performance of some breeding lines/cultivars in specific environments, making it one of the major problems of improvement programs, The procedure adopted to circumvent and minimize the magnitude of the interaction is the recommendation of cultivars with broad adaptability and high phenotypic stability (Barros et al., 2010a). There are several methods described in the literature regarding the study of the effects of the $G \times E$ interaction. The majority of the methods used in the studies of adaptability and stability can be used in conjunction, since they are complementary.
The most commonly used methods are based on the analysis of variance, and regression, in addition, others are based on bissegmented regression analysis. There are also nonparametric methods of analysis and visual analysis, besides the multivariate analysis of factors and principle components analysis (Carvalho et al., 2014). The terms adaptability and stability are related to the potential capacity of genotypes to positively assimilate environmental stimulus. Stability is considered as the capacity of genotypes to exhibit the most constant performance possible, as a function of environmental quality variations (Cruz et al., 2012; Ramalho et al., 2012). Among the methods of analysis of adaptability and stability the methodology of Verma et al. (1978), and synthesized by Cruz et al. (1989), is a prominent method, in which they proposed as stability analysis methodology and bissegmented linear regression, so that one segment of straight line would be adjusted for inferior or unfavorable environments, and the other for superior or favorable environments. Stability and adaptability, and environmental stratification studies, although recognized as important, have been conducted in isolation and are, therefore, of little benefit for genetic improvement. Thus, the breeder needs to make decisions, based on at least two methodologies, one complementing the other (Cruz and 
Carneiro, 2006). Based on these aspects, Murakami and Cruz (2004) proposed a methodology that includes, simultaneously, the adaptability and stratification analysis of environments through the principle of the similarity of genotype performance based on the multivariate technique of factor analysis. The biplot analysis method "additive main effects and multiplicative interaction model" (AMMI) is efficient in the analysis of cultivar adaptability and stability, because it allows an easier interpretation of the interaction in more than one dimension (Duarte and Vencovsky, 1999; Meotti et al., 2012). Furthermore, the AMMI analysis allows the graphical representation of the genotypes and the environments in a multivariate dispersion diagram (biplot). These diagrams provide information on phenotypic stability and adaptability for the choice of specific environments during the process of evaluation and selection of precommercial cultivars. Given the importance of the subject, studies have been developed with soybean (Stülp et al., 2009; Meiotti et al., 2012; Yokomizo et al., 2013).

Knowing the importance of the previous step involved in the indication of a cultivar for commercial launch, analysis of adaptability and stability, through different methodologies, should be explored extensively by breeders (Maia et al., 2014). The present work had as its objective to study the adaptability and stability of grain yield of soybean breeding lines and cultivars in different environments, using different adaptability and stability methodologies.

\section{Results and discussion}

\section{Analysis of variance}

The $G \times E$ interaction for the character grain yield was obtained for all the soybean genotypes and the evaluated environments (Table 2). Based on this premise, it is assumed that the analysis of adaptability and stability is valid. The $G x$ $E$ interaction shows that there are genotypes with specific adaptation and possibly genotypes with general adaptation. The results of Mendonça et al. (2007) corroborate with this work, where the analysis of factors and environmental stratification in the evaluation of the adaptability and stability of grain yield of 21 soybean genotypes from 2000 to 2003 in a total of 15 environments, found significant effects for all the sources of variation and indicated that the significant presence of $G \times E$ demonstrated the differentiated behavior of the cultivars in each environment and that there is a change in the range of responses to the character due to environmental variation, thus justifying the environmental stratification analysis. The coefficient of variation (CV) was satisfactory (10.57\%), given the range of environments tested. Similar values for CV in the state of Paraná were obtained by Carvalho et al. (2002), where the percentages were between $9.15 \%$ and $13.15 \%$ and Mendonça et al. (2007) with a mean CV of $13.73 \%$.

The performance evaluation of pre-launch soybean cultivars is conducted by evaluating trials of the cultivation value and use (VCU). This step is essential for the analysis of cultivar interaction with the environment. It is assumed that this is one of the most important steps in genetic improvement, since, there are great difficulties in the identification of superior and stable cultivars in all cultivation regions (Branquinho et al., 2014). When the existence of the significant interaction between genotypes and environments is verified, techniques are used to identify genotypes adapted and stable to specific environments (Dias et al., 2009). The $G \times E$ interaction is one of the major problems of improvement programs of any species, either in the selection phase of superior genotypes or in the recommendation of cultivars (Barros et al., 2010b). According to the authors, the alternatives employed to soften the influence of this interaction have been bypassed through the use of cultivars with broad adaptability (responsiveness) and stability (predictability).

\section{Environmental indices}

Regarding the evaluation of the environmental indices for each environment, the results indicated that, among 15 environments, eight were favorable to the cultivars evaluated, ie 1 (Assaí - E1); 2 (Assaí - E2); 5 (São Pedro do Ivaí - E2); 7 (Cornélio Procópio - E1); 8 (Cornélio Procópio E2); 10 (Marilândia do Sul - E1); 11 (Marilândia do Sul - E2) and 15 (Congonhinhas - E3), all with an mean yield greater than 64 bags ha ${ }^{-1}$, with a maximum of 72 bags ha $^{-1}$ found for environment seven (Table 3 ). These productivity values are considered promising, since the national average is 50 bags ha $^{-1}$ (Conab, 2015), ie, 22 bags ha $^{-1}$ lower than the results of this study. In this context, it can be inferred that among the tested cultivars the classification of place and time, such as environment, revealed that there are cultivars that respond satisfactorily to certain seasons and specific locations, and cannot be expanded to all the sites and/or sowing times. dos Reis Venturoso et al. (2009) showed that the cultivars have preferred sowing periods, where they are more likely to obtain high yields.

Regarding the mean yield values of the six soybean cultivars, the mean of cultivar SYN 1157 was superior to all the others, followed by SYN 1163 and SYN 1059 (Table 4). However, it should be noted that the six soybean cultivars all showed similar behavior for grain yield.

The lowest average yield of the 15 environments was observed in the cultivar SYN 1049, followed by cultivar SYN 3358. It was noteworthy that the cultivars SYN 1163, SYN 1157 and SYN 1059, had average yields above 60 bags ha $^{-1}$ in the less favorable conditions (Table 4). The highest mean yield was found for cultivar SYN 1157, followed by SYN 1059 and SYN 1163. For the amplitude of variation among the genotypes, the cultivars with the lowest oscillations were SYN 3358 and SYN 1059. The cultivars SYN 1157 and SYN 1049 showed the highest yield oscillations in the 15 environments.

\section{Bissegmented regression}

Regarding the adaptability parameters, the Cruz et al. (1989) method for bissegmented regression, we verified that the soyabean cultivars SYN 1152, SYN 3358, SYN 1163 and SYN 1157 did not respond significantly to unfavorable environments, with $ß 1=1.0$ (Table 4), indicating that there was no biological response to the unfavorable environments (Ramalho et al., 2014). On the other hand the cultivars SYN 1049 and SYN 1059 responded significantly to unfavorable environments. Regarding the $\beta 1+\beta 2$ component, it can be inferred that no cultivar showed significant effects $(B 1+\beta 2$ $>1$ ), which implies that there was no positive response to favorable environments. 
Table 1. Relationship of the sites, altitude and sowing times of six soybean cultivars, in Paraná during the 2011/2012 season.

\begin{tabular}{llcccc}
\hline & & & \multicolumn{3}{c}{ Sowing period } \\
\cline { 3 - 5 } Location & Municipality & Height $(\mathrm{m})$ & Period 1 & Period 2 & Period 3 \\
\cline { 3 - 5 } & & 635 & $15-20$ oct & 29 oct-03 nov & $15-20$ nov \\
\hline L1 & Assaí & 450 & 20 oct & 01 nov & 19 nov \\
L2 & São Pedro do Ivaí & 650 & 20 oct & 30 oct & 15 nov \\
L3 & Cornélio Procópio & 700 & 17 oct & 01 nov & 18 nov \\
L4 & Marilândia do Sul & 700 & 18 oct & 03 nov & 18 nov \\
L5 & Congonhinhas & & & & 19 nov \\
\hline
\end{tabular}

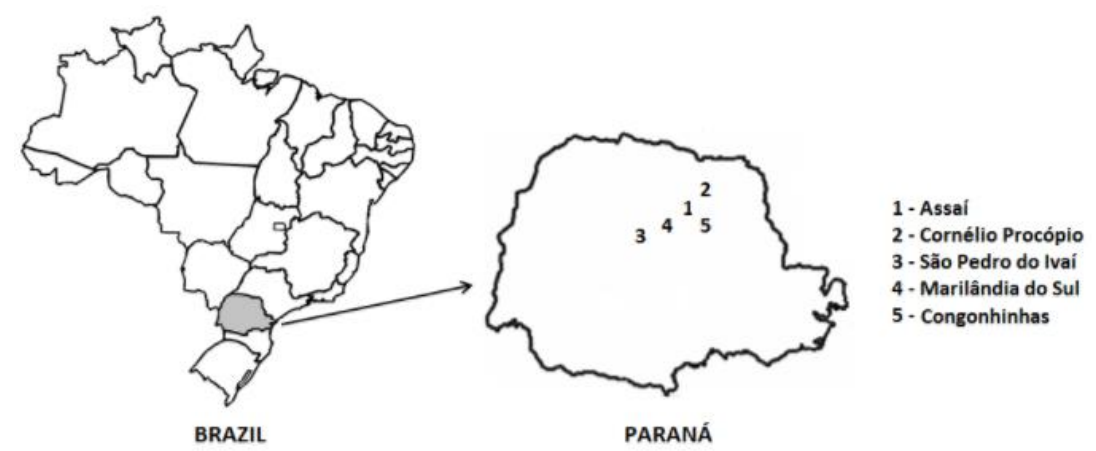

Fig 1. Location of the municipalities where work is carried out in the state of Paraná.

Table 2. Summary of the variation analysis for the character grain yield, evaluated for six soybean cultivars grown in 15 environments in the state of Paraná.

\begin{tabular}{|c|c|c|c|}
\hline Variation Factor & $\mathrm{GL}$ & $\mathrm{QM}_{\mathrm{RG}}$ & $\mathrm{F}$ \\
\hline Bloc/Env & 15 & 12.26 & \\
\hline Cultivar (C) & 5 & 331.82 & $2.72^{*}$ \\
\hline Environment $(\mathrm{E})$ & 14 & 362.28 & $29.53^{* *}$ \\
\hline $\mathrm{C}_{X} \mathrm{E}$ & 38 & 121.67 & $2.68^{* *}$ \\
\hline Residue & 40 & 45.32 & \\
\hline $\mathrm{CV}(\%)^{*}$ & & 10.57 & \\
\hline $\mathrm{Cv}_{\mathrm{G}} / \mathrm{Cv}_{\mathrm{E}}{ }^{* *}$ & & 0.39 & \\
\hline
\end{tabular}

$\mathrm{CV}(\%):$ Coefficient of variation of the environment, in percentage. ${ }^{* *} \mathrm{CVG} / \mathrm{CvE}$ : ratio between the genetic and environmental coefficient of variation.

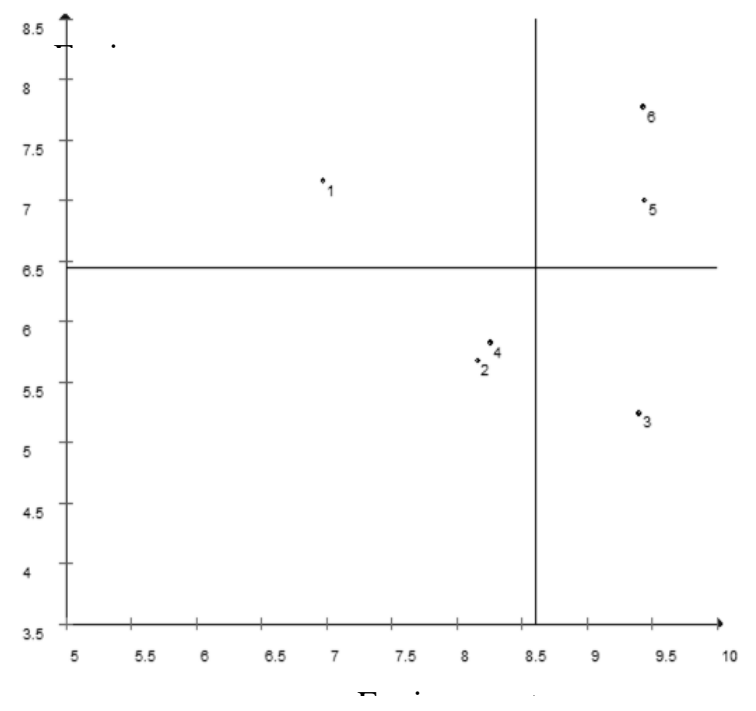

Fig 2. Plot of the scores, considering factors 1 and 2, referring to the results obtained from the factor analysis for six soybean cultivars evaluated in 15 environments in the state of Paraná. 
Table 3. Means for grain yield for the six soybean cultivars at 15 environments and the environmental indices.

\begin{tabular}{|c|c|c|c|c|c|}
\hline Environments & $\begin{array}{l}\text { Characterization of the } \\
\text { environments }\end{array}$ & Mean & Index (AJ) & Index T (AJ) & Type \\
\hline 1 & Assaí $-\mathrm{E}_{1}{ }^{*}$ & 66.91 & 3.27 & -1.01 & $\mathrm{~F}$ \\
\hline 2 & Assaí- $\mathrm{E}_{2}$ & 65.84 & 2.20 & -2.09 & $\mathrm{~F}$ \\
\hline 3 & Assaí- $\mathrm{E}_{3}$ & 59.13 & -4.50 & 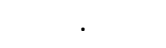 & $\mathrm{D}$ \\
\hline 4 & São Pedro do Ivaí- $E_{1}$ & 53.89 & -9.74 & & $\mathrm{D}$ \\
\hline 5 & São Pedro do Ivaí- $E_{2}$ & 67.11 & 3.47 & -0.81 & $\mathrm{~F}$ \\
\hline 6 & São Pedro do Ivaí-E $E_{3}$ & 56.59 & -7.04 & & $\mathrm{D}$ \\
\hline 7 & Cornélio Procópio - $\mathrm{E}_{1}$ & 72.01 & 8.37 & 4.08 & $\mathrm{~F}$ \\
\hline 8 & Cornélio Procópio- $E_{2}$ & 68.64 & 5.00 & 0.70 & $\mathrm{~F}$ \\
\hline 9 & Cornélio Procópio- $E_{3}$ & 56.55 & -7.08 & & $\mathrm{D}$ \\
\hline 10 & Marilândia do Sul- $E_{1}$ & 69.85 & 6.20 & 1.91 & $\mathrm{~F}$ \\
\hline 11 & Marilândia do Sul- $E_{2}$ & 68.61 & 4.97 & 0.68 & $\mathrm{~F}$ \\
\hline 12 & Marilândia do Sul- $E_{3}$ & 59.24 & -4.39 & . & $\mathrm{D}$ \\
\hline 13 & Congonhinhas $-\mathrm{E}_{1}$ & 63.00 & -0.64 & . & $\mathrm{D}$ \\
\hline 14 & Congonhinhas $-E_{2}$ & 62.71 & -0.92 & 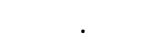 & $\mathrm{D}$ \\
\hline 15 & Congonhinhas $-E_{3}$ & 64.47 & 0.83 & -3.45 & $\mathrm{~F}$ \\
\hline
\end{tabular}

${ }^{*} E_{1} ; E_{2}$ and $E_{3}$ refer to sowing times one, two and three in each environment.

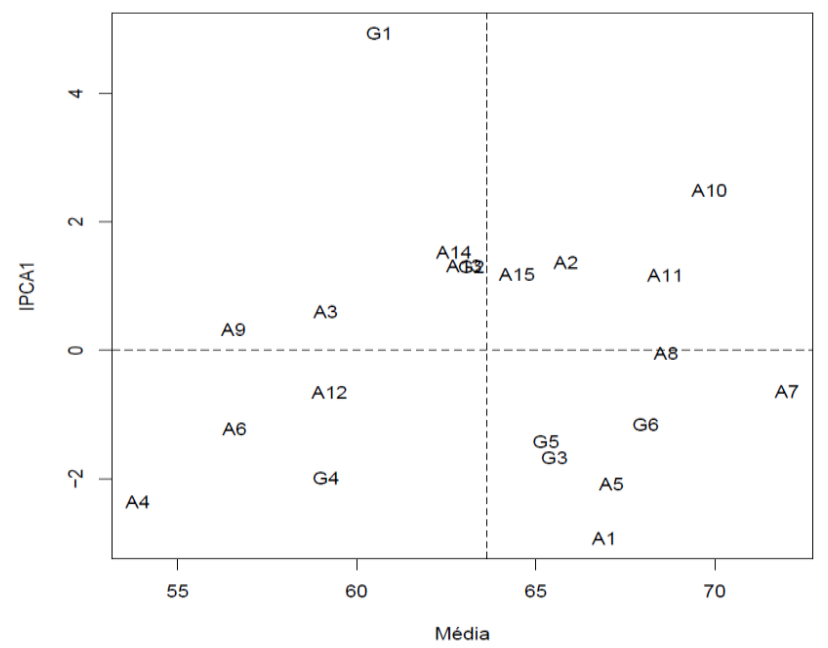

Fig 3. AMMI analysis biplot (productivity vs. IPCA1) for the grain yield of six cultivars (G1 to G6) SYN 1049 (1); SYN 1152 (2); SYN 1059 (3); SYN 3358 (4); SYN 1163 (5); SYN 1157 (6) evaluated in 15 environments (A1 to A15) [location Assaí-PR (A1 season 1, A2 season 2, A3 season 3)], [local São Pedro do Ivaí-PR (A4 season 1, A5 season 2 , A6 season 3)], [Cornelio Procópio-PR (A7 season 1 , A8 season 2, A9 season 3)], [Marilândia do Sul-PR (A10 season 1, A11 season 2, A12 season 3) and [Congonhinhas-PR (A13 season 1, A14 season 1, A15 season 3)].

Table 4. Adaptability and stability parameters estimated according to Cruz et al. (1989), for six soybean cultivars, in 15 environments within the state of Paraná.

\begin{tabular}{|c|c|c|c|c|c|c|c|c|c|}
\hline \multirow[b]{2}{*}{ Cultivar } & \multicolumn{3}{|c|}{ Mean in the Environments } & & \multirow[t]{2}{*}{ ß1 } & \multirow[t]{2}{*}{ ß2 } & \multirow{2}{*}{$\beta 1+ß 2$} & \multirow[t]{2}{*}{$Q_{\text {MDesv }}$} & \multirow[t]{2}{*}{$\mathrm{R}^{2}$} \\
\hline & Mean & Unfavorable & Favorable & & & & & & \\
\hline SYN 1049 & 60.63 & 55.50 & 65.11 & $1.36^{*}$ & $-0.62^{\text {NS }}$ & & $0.74^{\mathrm{NS}}$ & $141.45^{*}$ & 46.51 \\
\hline SYN 1152 & 63.20 & 58.42 & 67.37 & $1.02^{\mathrm{NS}}$ & $0.86^{\mathrm{NS}}$ & & $1.89^{\mathrm{NS}}$ & $26.22^{\mathrm{NS}}$ & 77.64 \\
\hline SYN 1059 & 65.52 & 61.39 & 69.13 & $0.64^{*}$ & $0.90^{\mathrm{NS}}$ & & $1.54^{\text {NS }}$ & $36.56^{\mathrm{NS}}$ & 53.41 \\
\hline SYN 3358 & 59.14 & 55.46 & 62.36 & $0.65^{\text {NS }}$ & $-0.22^{\mathrm{NS}}$ & & $0.43^{\mathrm{NS}}$ & $35.91^{\text {NS }}$ & 44.66 \\
\hline SYN 1163 & 65.28 & 6072 & 69.27 & $0.96^{\text {NS }}$ & $0.84^{\mathrm{NS}}$ & & $1.80^{\mathrm{NS}}$ & $40.51^{\text {NS }}$ & 66.59 \\
\hline SYN 1157 & 68.06 & 6089 & 74.34 & $1.33^{\mathrm{NS}}$ & $-1.76^{*}$ & & $-0.42^{*}$ & $45.66^{\mathrm{NS}}$ & 71.72 \\
\hline
\end{tabular}

General Mean

63.64

*: Significantly different from one, by the t test, at 5 and $1 \%$ probability. ${ }^{* *}$ : Significantly different from zero, by test $\mathrm{F}$, at $5 \%$ probability. NS: not significant. $\mathrm{b}_{1 i}:$ general mean of the cultivar $i ; b_{2 i}$ : linear regression coefficient associated with unfavorable environments; $b_{1 i}+b_{2 i}$ : linear regression coefficient associated with favorable environments. 


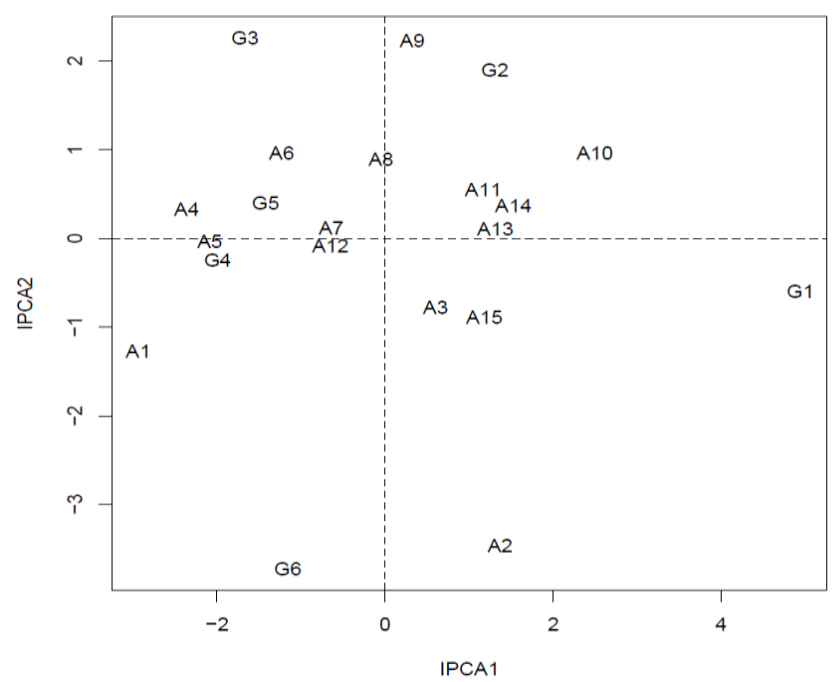

Fig 4. AMMI2 biplot (IPCA1 vs. IPCA2) for the grain yield of 6 cultivars (G1 to G6) SYN 1049 (1); SYN 1152 (2); SYN 1059 (3); SYN 3358 (4); SYN 1163 (5); SYN 1157 (6) evaluated in 15 environments (A1 to A15) [location Assaí-PR (A1 season 1, A2 season 2, A3 season 3)], [location São Pedro do Ivaí-PR (A4 season 1, A5 season 2 , A6 season 3)], [Cornelio Procópio-PR (A7 season 1, A8 season 2, A9 season 3)], [Marilândia do Sul-PR (A10 season 1, A11 season 2, A12 season 3) and Congonhinhas-PR (A13 season 1, A14 season 1, A15 season 3)].

Table 5. Summary of the factor analysis for the grain yield of six soybean cultivars evaluated in 15 environments in the state of Paraná.

\begin{tabular}{|c|c|c|c|c|c|c|c|c|}
\hline \multicolumn{3}{|c|}{ Estimation of eigenvalues } & \multirow{2}{*}{ Environment } & \multicolumn{5}{|c|}{ Factor loads after rotation } \\
\hline Root & Root (\%) & Accumulated (\%) & & Factor 1 & Factor 2 & Factor 3 & $\mathrm{Com}^{1}$ & $\mathrm{IA}^{2}$ \\
\hline 5.89 & 39.25 & 39.25 & 1 & 0,83 & 0,04 & $-0,48$ & 0,92 & 3,28 \\
\hline 5.14 & 34.27 & 73.52 & 2 & 0.01 & 0.79 & 0.13 & 0.65 & 2.20 \\
\hline 2.53 & 16.85 & 90.37 & 3 & 0.29 & 0.91 & 0.21 & 0.96 & -4.51 \\
\hline 0.94 & 6.26 & 96.62 & 4 & 0.92 & -0.23 & -0.11 & 0.90 & -9.75 \\
\hline 0.51 & 3.38 & 100.00 & 5 & 0.98 & 0.03 & 0.08 & 0.96 & 3.48 \\
\hline 0.00 & 0.00 & 100.00 & 6 & 0.86 & -0.36 & -0.12 & 0.88 & -7.05 \\
\hline 0.00 & 0.00 & 100.00 & 7 & 0.80 & 0.34 & 0.28 & 0.83 & 8.38 \\
\hline 0.00 & 0.00 & 100.00 & 8 & 0.71 & -0.05 & 0.70 & 1.00 & 5.00 \\
\hline 0.00 & 0.00 & 100.00 & 9 & 0.17 & -0.79 & 0.55 & 0.96 & -7.08 \\
\hline 0.00 & 0.00 & 100.00 & 10 & -0.63 & -0.05 & 0.69 & 0.87 & 6.21 \\
\hline 0.00 & 0.00 & 100.00 & 11 & 0.23 & 0.30 & 0.93 & 1.00 & 4.98 \\
\hline 0.00 & 0.00 & 100.00 & 12 & 0.90 & 0.30 & 0.15 & 0.88 & -4.40 \\
\hline 0.00 & 0.00 & 100.00 & 13 & -0.40 & 0.59 & 0.54 & 0.80 & -0.64 \\
\hline 0.00 & 0.00 & 100.00 & 14 & -0.13 & 0.41 & 0.90 & 1.00 & -0.92 \\
\hline 0.00 & 0.00 & 100.00 & 15 & -0.02 & 0.88 & 0.42 & 0.95 & 0.83 \\
\hline
\end{tabular}

${ }^{1}$ Comunalities; ${ }^{2}$ Environmental Index.

The bissegmented linear regression model, proposed by Cruz et al. (1989), tests the significance of the 32 hypothesis ( $\mathrm{HO}$ : ß2=0); if the hypothesis is not rejected, it implies that the model is not segmented, as is proposed by Eberhart and Russel (1966), it is sufficient to explain the behavior of soybean cultivars (Ramalho et al., 2014). Under the conditions of this study (Table 4), all the cultivars, except SYN 1049, accepted the null hypothesis (HO: $ß 2=0)$, indicating that the bissegmented linear regression model was partially sufficient in explaining the results. However, given the ranges of the coefficients of determination, it can be concluded that they are not sufficiently high enough. Therefore, to confirm, more detailed complementary analyses are required.

Regarding the stability estimates (Table 4), it was observed that the cultivars SYN 1152, SYN 1059, SYN 3358, SYN 1163 and SYN 1157, whose estimates of regression deviations $\left(Q_{\text {MDesv }}\right)$ did not differ from zero, indicating they possessed stability (predictability) for grain yield. However, the means of cultivars SYN 1059 and SYN 1157 were high and with high predictability, non-significant deviations, suggesting these cultivars have a high agronomic potential for the evaluated regions. The soybean cultivar with the highest mean grain yield was stable in the environments.

\section{Factor analysis}

Regarding the factor analysis, looking for the establishment of combinations of lines, that permit the interpretation relating to the environment groups with the same genotypic discrimination pattern, capable of retaining the maximum of the associations originally available among the studied environments. The grouping of environments is carried out using the information about the range of the final factorial loads. Factorial loads greater than or equal to 0.7 in absolute values indicate environments with high correlations, and are 
grouped within each factor; factorial loads with low values ( $\leq$ 0.50 ) indicate that the respective environment should not belong to the group; and factorial loads with intermediate values ( $\geq 0.50$ and $\leq 0.70$ ) do not guarantee any definition of grouping (Cruz and Carneiro, 2006).

Regarding the eigenvalue estimates, it is necessary, for a satisfactory explanation of the data in the analysis of factors, that the cumulative eigenvalues are greater than $80 \%$. To meet this parameter, we considered $1 ; 2$ and 3 factors $90.37 \%$ of the variability (Table 5 ). It was found that, after the rotation, factor 1 indicates the possibility of grouping of the environments 1 (Assaí - E1), 4; 5; 6 (São Pedro do Ivaí E1 - E2 - E3), 7 (Cornélio Procópio - E1), 8 (Cornélio Procópio -E2) and 12 (Marilândia do Sul - E3), all with factorial loads of 0.80 or more. For factor 2, the environments 2, 3 (Assaí E2 - E3), and 15 (Congonhinhas E3) were grouped together and for factor 3 the environments 11 (Southern Marinha E2) and 14 (Congonhinhas E3 were grouped. The environments 9 (Cornélio Procópio - E3), 10 (Marilândia do Sul - E1) and 13 (Congonhinhas E1), were not grouped by any factor, since their factorial loads were below 0.70 for all three of the factors considered, such estimates do not guarantee any definition of grouping with other environments (Cruz and Carneiro, 2006).

Non-clustered environments were reported for the soybean by Mendonça et al. (2007), during adaptability studies in the Southern Region of Brazil. The authors managed to group most of the environments, data that corroborate this study, in which only $20 \%$ of the environments $(9,10$ and 13$)$ were not grouped by any of the considered factors.

The environments 4; 5 and 6 (São Pedro do Ivaí - E1, E2 and E3) were grouped in factor 1 , indicating that the three sowing times, at this site, similarly influenced the grain yield of the soybean cultivars (Table 5). However, for factors 2 and 3 there was no grouping of seasons, demonstrating how much the variation of the sowing season can affect the grain yield of the cultivars. According to Meotti et al. (2012), the sowing time is the predominant factor for the success of the crop, since they result in alterations to water relations, as well as in the temperature, photoperiod and solar radiation available to plants.

To make use of the information of the factor analysis, it is fundamental that each variable considered can be adequately represented by the common factors, which permits inference on the strata of environments and on the adaptability of the studied genotypes (Cruz and Carneiro, 2006). The commonalities for all the environments presented estimates above $65 \%$, revealing a high efficiency in the representation of variables by a common part (Table 5). According to Cruz and Carneiro (2003), commonality values above $64 \%$ are considered satisfactory, since, they indicate a correlation above $80 \%$ between standard variables and the common part.

Regarding the environmental index, the environments 1 ; $2 ; 5 ; 7 ; 8 ; 10 ; 11$ and 15 were indicated as favorable (positive indices), while the others were considered unfavorable (negative indices) (Table 5) for grain yield.

\section{AMMI analysis}

The first principle axis of the AMMI analysis (IPCA1), responsible for the highest percentage of the standard linked to the interaction, obtained $56.8 \%$ of the variation of the $S_{G X E}$ (data not shown). The range of variation retained in this first component was found to be above the proportions obtained in similar studies with soybean, performed by Maia et al. (2006) (39.85\%) and Yokomizo et al. (2013) (44\%).

Based on this result, it is possible to point out that for the grain yield character evaluated in the present study, more than half of the variation related to the deviation from additivity of the principle effects (genotypes and environments) can be captured by the IPCA1 interaction (Duarte and Vencovsky, 1999).

Regarding the other components evaluated, according to their contributions, only the IPCA2 component, with $23.36 \%$ of the variation retained, showed significance (data not shown). Therefore, the first two principle components were responsible for explaning $80.16 \%$ of the $\mathrm{SQ}_{\mathrm{GXE}}$. The range of variation captured by these two components can be considered as the "standard" associated with the $\mathrm{G} \times \mathrm{E}$ interaction, for the model-data set analyzed in the present study. In this sense, the other components, responsible explaining approximately $20 \%$ of the $\mathrm{SQ}_{\mathrm{GXE}}$ variation, were discarded from the analysis because they are principally "noises" (Silva and Benin, 2012; Yokomizo et al., 2013). The sum of the first two components is in agreement with other soybean studies using AMMI biplots, where the first two components explained between $61 \%$ and $88 \%$ of the $\mathrm{SQ}_{\mathrm{GXE}}$ and were significant (Campbell and Jones, 2005; Tarakanovas and Sprainaitis, 2005; Al., 2006).

In the analysis of soybean cultivars or environments whose points are closer to the origin of the coordinate system in the AMM1 biplot (Fig 3) and AMM2 (Fig 4) are considered stable. However, it was observed that from the cultivars evaluated there was considerable dispersion, which indicates interaction with environments, or that they presented specific adaptations with certain environments (Duarte and Vencovsky, 1999). The cultivar SYN 1049 contributed the most to the $\mathrm{G} \times \mathrm{E}$ interaction, since it presented the greatest range of score in the interaction axis. The soybean cultivars SYN 1059, SYN 1163 and SYN 1157 were associated with the environments $A 1, A 5, A 7$ and $A 8$, as they belonged to the same quadrant and thus were demonstrated to be more adapted to these specific environments. These results are in agreement with the observations reported in the analysis of factors that indicated that these genotypes have specific adaptability.

The analysis of the stability is linked to the separation of the $y$-axis genotypes, this analysis indicted that the cultivars SYN 1152, SYN 1059 and SYN 1163 were the closest, which indicates that these cultivars are stable. The cultivars SYN 1059 and SYN 1163 stood out as they were to the right of the biplot, in that, they revealed a higher general mean for the tests. Thus, for the purpose of cultivar recommendation it is desired, in addition to stability, high agronomic performance, therefore the SYN 1152, SYN 1059 and SYN 1163 stood out among the evaluated cultivars in the present work. It can be emphasized that the AMMI analysis considering the IPCA1 vs. mean was more detailed in the dispersion of the genotypes, since the bisegmented regression analysis indicated a further two cultivar as stable. The refinement in the interpretation of the analysis when aggregating the AMMI2 biplot (Fig 4), allows the correcting or ratifying of the adaptive behavior of the cultivars given 
their significance. Therefore, the stable behavior of SYN 1163 and SYN 3358 was confirmed. However, SYN 1152 and SYN 1059, apparently stable only under the first axis (IPCA1), now revealed their contribution to the $G \times E$ interaction captured on the second major axis (IPCA2). This is contrary to their productive stability, which shows that IPCA1 alone is not sufficient to infer the predictability of the cultivars. It is important to mention that the factors related to the $\mathrm{G} \times \mathrm{E}$ interaction explained by the first axis are statistically independent of those that determine the interaction captured by the second axis, in this sense there should be no loss of generality in cases involving a greater number of selected axes, in that these factors and their mathematical constructs with significant effects (Yokomizo et al., 2013). However, the analysis of both the IPCA1 and IPCA2 axes confirmed the high instability of SYN 1049.

The environments $A 1, A 2, A 4, A 5, A 6, A 7, A 9$ and $A 10$ were the main contributors to the $G \times E$ interaction, the distance of the central point of the axes can be highlighted along with the quadrant changes observed in both IPCA1 and IPCA2.

In the AMMI analyses, when considering the two components IPCA1 and IPCA2 and the bissegmented regression, no cultivar revealed a wide adaptability to the 15 evaluation environments, highlighting the environmental influence of the seasons and cultivation sites to which the cultivars were subjected. It is also possible to infer, that the results of the two methodologies are in agreement regarding the classification of the genotypes, with the greatest unpredictability of response being the cultivars SYN 1049 and SYN 1157 with higher oscillations.

The factor analysis and AMMI were concordant, when considering the IPCA1 for the classification of cultivars with specific adaptability, classifying the cultivars SYN 1157, SYN 1163 and SYN 1059 with specific adaptability and also relating the classification of the low yield performance of the SYN 3358 cultivar in the different environments. Regarding the classification of the environments, the three methodologies were partially concordant, where previously A10, A11 and A15 were classified in an unusual way by the proposed methods as favorable to cultivars.

\section{Materials and methods}

\section{Plant materials}

The experiment was carried out during the 2011/2012 season, at five distinct locations, in the State of Paraná (Table 1, Fig 1), using three different sowing times for each site and six cultivars, all with the RR ${ }^{\circ}$ technology: SYN 1049 (1); SYN 1152 (2); SYN 1059 (3); SYN 3358 (4); SYN 1163 (5); SYN 1157 (6). The soil all had similar physico-chemical characteristics, to minimize the effect of the terrain on the performance of the cultivars. The soil of the five sites was characterized as a Red Latosol. The basic fertilization regime consisted of the application, to all areas, of approximately $320 \mathrm{~kg} \mathrm{ha}^{-1}$ of $02-20-20$ (NPK) formulation, since the areas were similar.

\section{Traits measured}

Grain yield was the character analyzed, this was obtained by harvesting $50 \mathrm{~m}^{2}$ of the experimental unit and then, after correcting $13 \%$ for moisture, extrapolating to $\mathrm{Kg} \mathrm{ha}^{-1}$.

\section{Experimental design}

A randomized complete block experimental design was used, with three replications. Each experimental unit was 10 meters long $x 10$ meters wide $\left(100 \mathrm{~m}^{2}\right)$. The sowing density for all the environments was 300,000 plants $\mathrm{ha}^{-1}$, with a spacing of 0.45 meters between rows.

\section{Statistical analysis}

The model used for the analysis of variation was $Y_{i j k}=m+G_{i}$ $+B_{k}+A_{j}+G A_{i j}+E_{i j k}$, where: $Y_{i j k}$ : observation for the plot that received treatment $i$ in environment $j$ in block $k$; M: overall mean of the experiment; $G i$ : effect of genotype $i(i=1,2, \ldots$, $p)$; $B k$ : effect of the block $k(k=1,2, \ldots, q) ; A_{j}$ : effect of the environment $j ;(j=1,2, \ldots, a) ; \mathrm{GA}_{\mathrm{ij}}$ : effect of the interaction of genotype $i$ with environment $j$; $\mathrm{E}_{\mathrm{ijk}}$ : experimental error associated with observation $i$ in environment $j$ in block $k$; The statistical model of bissegmented linear regression of Cruz et al. (1989) is as follows:

$\overline{\mathrm{y}}_{\mathrm{ij}}=\mathrm{b}_{\mathrm{oi}}+\mathrm{b}_{1 i} \mathrm{l}_{\mathrm{j}}+b_{2 i} \mathrm{~T}\left(l_{j}\right) \delta_{\mathrm{ij}}+\overline{\mathrm{e}}_{\mathrm{ij}}$, where:

$\bar{y}_{i j}$ : estimated mean of genotype $i$ in environment $j ; b_{o i}$ : intercept or mean of genotype $i ; b_{1 i}$ : regression coefficient of genotype $i ; \quad l_{j}$ : is the environmental index used by Eberhart and Russel (1966); $T(I j)$ is a variable, where $T(I j)=$ 0 , if $I_{j}<0$ and $T\left(I_{j}\right)=I_{j}-I_{+}$, if $I_{j}>0$, where $I_{+}$the mean of the positive $l_{j}$ indices, $\delta_{i j}$ : deviation of the regression of genotype $i$ in the environment $j ; \bar{e}_{i j}$ : is the mean experimental error.

Thus, in unfavorable environments $(\mathrm{l} j<0)$ we have:

$$
\bar{y}_{i j}=b_{o i}+b_{1 i} l_{j}+\delta_{i j}+\bar{e}_{i j}
$$

and in favorable environments $\left(I_{j}<0\right)$ the regression model becomes:

$\overline{\mathrm{y}}_{\mathrm{ij}}=\mathrm{b}_{\mathrm{oi}}+\mathrm{b}_{1 i} \mathrm{l}_{\mathrm{j}}+b_{2 i} l_{j}+\delta_{\mathrm{ij}}+\overline{\mathrm{e}}_{\mathrm{ij}}=b_{0 i}+\left(b_{1 i}+b_{2 i}\right) l_{j}+\delta_{i j}+\bar{e}_{i j}$ where in:

$b_{1 i}$ is the linear response to the unfavourable environments and $\left(b_{1 i}+b_{2 i}\right)$ relative to the favorable environments. The parameter $b_{o i}$ corresponds to the average of cultivar $i$ in all environments.

To complement the bissegmented regression analysis for the parameters adaptability and stability of grain yield, a factor analysis was conducted according to the methodology of Murakami and Cruz (2004).

The data were initially submitted to analysis of variance by the F-test. When the significant effects for $G \times E$, for the character grain yield, were found, complementary analysis were conducted. Analyzes of adaptability and stability were performed according to the methodology of bissegmented regression analysis, Cruz et al. (1989) model. Factor analysis, following the methodology of Murakami and Cruz (2004), and AMMI analysis were also conducted. To define the number of main axes to be retained, to explain and represent graphically the pattern related to the $G \times E$ interaction, we adopted the criteria used by Zobel et al. (1998). The $F_{G o l l o b}$ significance test was used as a stopping point that determines the selection of the model in the AMMI family of models, for successive terms of interaction, it also combined the other terms not retained in the selected model in complementary sections of the $\mathrm{SG}_{\mathrm{GXE}}$ by the Cornelius F test (Cornelius et al., 1992; Piepho, 1995).

The software used for the statistical analysis was the computational program Genes (Cruz, 2013). The analysis of the adaptability and stability via AMMI was performed using the GLM and IML procedures of the SAS (Institute, Cary, NC, 
USA) computer application, described in detail in Duarte and Vencovsky (1999).

\section{Conclusion}

Estimates of the environmental indices by the bisegmented regression analysis, factor analysis and AMMI are partially concordant in the classification of favorable and unfavorable environments for the cultivars. The bisegmented regression and AMMI methodologies did not reveal cultivars with broad adaptability to the 15 evaluated environments. The factor and AMMI analyses allowed the classification of the cultivars related to the specific environmental conditions, which increases the yield of the cultivar. The specific adaptability of the soybean cultivars SYN 1059 and SYN 1163 was revealed by the three analysis methodologies. These also revealed stability through both the bissegmented regression method and the IPCA1 vs. mean. The attainment of high yield levels is directly related to the choice of the cultivar, the location and the sowing season.

\section{References}

Barros HB, Sediyama T, Texeira RC, Fidelis RR, Cruz CD, Reis MS (2010a) Adaptabilidade e estabilidade de genótipos de soja avaliados no estado do Mato Grosso. Rev Ceres. 57:359-366.

Barros HB, Sediyama, T, Cruz CD, de Cássia Teixeira R, Reis MS (2010b) Análise de adaptabilidade e estabilidade em soja (Glycine max L.) em Mato Grosso. Ambiência, 6:75-88.

Branquinho RG, Duarte JB, de Souza PIM, da Silva Neto SP, Pacheco RM (2014) Estratificação ambiental e otimização de rede de ensaios de genótipos de soja no Cerrado. Pesqui Agropecu Bras Sér Agron. 49:783-795.

Campbell BT, Jones MA (2005) Assessment of genotype $x$ environment interactions for yield and fiber quality in cotton performance trials. Euphytica. 144:69-78.

Carvalho ADF, da Silva GO, Pereira RB, Pinheiro JB (2014) Análise de fatores e regressão bissegmentada no estudo da adaptabilidade e estabilidade de cenoura. Rev Ceres. 61:932-940.

Carvalho CGP, Arias CAA, Toledo JFF, Almeida LA, Kiihl RAS, Oliveira MF (2002) Interação genótipo $x$ ambiente no desempenho produtivo da soja no Paraná. Pesqui Agropecu Bras Sér Agron. 37:989-1000.

Cavalcante AK, Hamawaki OT, Hamawaki RL, Sousa LB, Nogueira APO, Hamawaki CDL (2014) Adaptabilidade e estabilidade fenotípica de genótipos de soja em Porto Alegre do Norte, MT. Biosci J. 30:942-949.

Conab. Companhia Nacional de Abastecimento. Acompanhamento da Safra Brasileira. Grãos. Quarto Levantamento Janeiro/2015. Safra 2014/2015. http://www.conab.gov.br/ OlalaCMS/ uploads/arquivos/15_01_09_09_00_21_boletim graos ja neiro_2015.pdf.

Cornelius PL, Seyedsadr M, Crossa J (1992) Using the shifted multiplicative model to search for "separability" in crop cultivar trials. Theor Appl Genet. 84:161-172.

Cruz CD, Torres RA, Vencovsky AR (1989) An alternative approach to the stability analysis proposed by Silva and Barreto. Rev Bras Genét. 12:567-580.

Cruz CD, Carneiro PCS (2003) Modelos biométricos aplicados ao melhoramento genético. Viçosa, UFV. 585p.
Cruz CD, Carneiro PCS (2006) Modelos biométricos aplicados ao melhoramento genético. 2a ed. v.2. Viçosa: UFV. 585p.

Cruz CD, Regazzi AJ, Carneiro PCS (2012) Modelos biométricos aplicados ao melhoramento genético. 4a ed.Viçosa: UFV. 514p.

Cruz CD (2013) Genes - a software package for analysis in experimental statistics and quantitative genetics. Acta Sci Agron. 35:271-276.

Dias FTC, Pitombeira JB, Teófilo EM, de Sousa Barbosa F (2009) Adaptabilidade e estabilidade fenotípica para o caráter rendimento de grãos em cultivares de soja para o Estado do Ceará. Rev Ciênc Agron. 40:129-134.

Duarte JB, Vencovsky R (1999) Interação genótipos x ambientes: uma introdução à análise AMMI. Ribeirão Preto: Soc Bras Genét. 60p.

Eberhart SA, Russell WA (1966) Stability parameters for comparing varieties. Crop Sci. 6:36-40.

Kaya Y, Akçura M, Taner S (2006) GGE-biplot analysis of multi-environment yield trials in bread wheat. Turkish $\mathrm{J}$ Agric For. 30:325-337.

Júnior WC, Duarte JB (2006) Métodos estatísticos para estudo de adaptabilidade e estabilidade fenotípica em soja. Pesqui Agropecu Bras Sér Agron. 41:23-30.

Maia MCC, Vello NA, de Araújo LB, dos Santos Dias CT, de Oliveira LC, de Moura Rocha M (2014) Interação genótipoambiente em soja via análise de componentes principais com múltiplas matrizes de dados. Rev. Agro@mbiente. 8:104-111.

Maia MCC, Vello NA, Rocha M de M, Pinheiro JB, Silva Júnior NF da (2015) Adaptabilidade e estabilidade de linhagens experimentais de soja selecionadas para caracteres agronômicos através de método uni-multivariado. Bragantia. 65:215-226.

Mendonça O, Carpentieri-Pípolo V, Garbuglio DD, Fonseca Junior NS (2007) Análise de fatores e estratificação ambiental na avaliação da adaptabilidade e estabilidade em soja. Pesqui Agropecu Bras Sér Agron. 42:1567-1575.

Meotti GV, Benin G, Silva RR, Beche E, Munaro LB (2012) Épocas de semeadura e desempenho agronômico de cultivares de soja. Pesqui Agropecu Bras Sér Agron. 47:1421.

Murakami DM, Cruz CD (2004) Proposal of methodologies for environment stratification and analysis of genotype adaptability. Crop Breed App. Biotechnol. 4:7-11.

Piepho HP (1995) Robustness of statistical test for multiplicative terms in the additive main effects and multiplicative interaction model for cultivar trial. Theor Appl Genet. 90:438-443.

dos Reis Venturoso L, Caron BO, Schmidt D, Bergamin AC, Júnior DDV, Jakelaitis A (2009) Efeito da época de semeadura sobre caracteres agronômicos em cultivares de soja em Rolim de Moura-RO. Biosci J. 25:73-81.

Tarakanovas P, Sprainaitis A (2005) Main additive effect and multiplicative interaction analysis of white clover genetic resources. Biologija. 4:38-42.

Ramalho MAP, Abreu AFB, Santos JB, Nunes JAR (2014) Aplicações da Genética Quantitativa no Melhoramento de Plantas Autógamas. 1ed. Lavras: ed. UFLA. 522p.

Stülp M, Braccini AL de, Albrecht LP, Ávila MR, Scapim CA, Schuster I (2009) Desempenho agronômico de três cultivares de soja em diferentes épocas de semeadura em duas safras. Ciênc Agrotec. 33:1240-1248. 
Verma MM, Chahal GS, Murty BR (1978) Limitations of conventional regression analysis: a proposed modification. Theor Appl Genet. 53:89-91.
Yokomizo GKI, Duarte JB, Vello NA, Unfried JR (2013) Análise AMMI da produtividade de grãos em linhagens de soja selecionadas para resistência à ferrugem asiática. Pesqui Agropecu Bras Sér Agron. 48:1372-1380.

Zobel RW, Wright MJ, Gauch HG (1988) Statistical analysis of a yield trial. Agron J. 80:388-393. 